\title{
Maternal Placental Blood Flow Is Reduced in Proportion to Reduction in Uterine Driving Pressure ${ }^{1}$
}

\author{
MARY R. LAIRD, J. JOB FABER, AND NANCY D. BINDER \\ Departments of Pediatrics and Physiology, Oregon Health Sciences University, Portland, \\ Oregon 97201-3098
} \begin{abstract}
ABST
The relationship between uterine driving pressure and ma-
ternal placental blood flow was studied after inflation of an aortic occluder previously placed between the renal and ovarian arteries in 10 conscious pregnant rabbits at $28 \pm 1$ (mean \pm SEM) $\mathrm{d}$ of a 30- to 31-d gestation to test the hypothesis that there is autoregulation of maternal placental blood flow. After control measurements, the femoral artery pressure was reduced $22 \pm 3 \%$ from $83 \pm 5 \mathrm{~mm} \mathrm{Hg}$ and clamped at $65 \pm 4 \mathrm{~mm}$ $\mathrm{Hg}(p<0.001)$ for $54 \pm 4 \mathrm{~min}$ by servo control. Carotid artery pressure increased from $86 \pm 5$ to $98 \pm 6 \mathrm{~mm} \mathrm{Hg}(p<0.01)$. There was no change in cardiac output $(839 \pm 78$ vs $814 \pm 64$ $\mathrm{mL} / \mathrm{min}$; NS), upper-body flow (651 $\pm 62 \mathrm{vs} 671 \pm 55 \mathrm{~mL} / \mathrm{min}$; NS), or renal flow (111 $\pm 14 v s 104 \pm 8 \mathrm{~mL} / \mathrm{min}$; NS). Blood flow to tissues below the occluder decreased from $188 \pm 18$ to $143 \pm 14 \mathrm{~mL} / \mathrm{min}$ for the lower body ( $p<0.05), 153 \pm 15$ to $116 \pm 11 \mathrm{~mL} / \mathrm{min}$ for the hindquarters $(p<0.05)$, and $17.7 \pm$ 1.9 to $12.9 \pm 1.4 \mathrm{~mL} / \mathrm{min}$ for 13 pregnant uterine horns $(p<$ 0.05). Placental flow to live fetuses per horn decreased from $13.0 \pm 1.9$ to $8.9 \pm 1.2 \mathrm{~mL} / \mathrm{min}(p<0.01)$, whereas there was no significant change in myoendometrial flow $(4.0 \pm 0.3 v s 3.5$ $\pm 0.5 \mathrm{~mL} / \mathrm{min}$; NS). Uterine oxygen consumption was unchanged $(1.15 \pm 0.16$ vs $1.06 \pm 0.13 \mathrm{~mL} / \mathrm{min}$; NS $)$. There was no change in the circulating arterial concentration of angioten-
\end{abstract}

At present, it is not known how maternal placental blood flow changes in response to acute reductions in maternal arterial blood pressure. Previous studies in sheep $(1,2)$ and rabbits $(3)$ have not examined the relationship between uterine driving pressure and maternal placental blood flow per se but have looked at the combined uteroplacental blood flow as an indirect measure of placental blood flow. Results obtained for the two species differed. Greiss (2) reported that uteroplacental blood flow in the anesthetized ewe decreases in proportion to

Received October 20, 1993; accepted February 14, 1994

Correspondence: Nancy D. Binder, M.D., Ph.D., Department of Pediatrics, Oregon Health Sciences University, 3181 S.W. Sam Jackson Park Rd., Portland, OR 97201-3042.

Supported by the Oregon Affiliate of the American Heart Association and NIH Grant 1-R29 HL44941-01A1.

${ }^{1}$ Presented in part at the Society for Pediatric Research meeting in Washington, DC, May 6, 1993. $\sin \mathrm{I}\left(2.95 \pm 1.07\right.$ vs $\left.1.46 \pm 0.59 \mathrm{ng} \cdot \mathrm{mL}^{-1}\right)$ or active plasma renin activity $\left(8.83 \pm 3.72\right.$ vs $\left.10.70 \pm 5.56 \mathrm{ng} \cdot \mathrm{mL}^{-1} \cdot \mathrm{h}^{-1}\right)$, but trypsin-activated total plasma renin activity increased from $20.24 \pm 2.39$ to $27.34 \pm 5.33 \mathrm{ng} \cdot \mathrm{mL}^{-1} \cdot \mathrm{h}^{-1}(p<0.05)$. There was neither a uterine venoarterious difference nor a net uterine release of angiotensin I or active plasma renin activity at any time, but the net uterine release of total plasma renin activity increased from $31.66 \pm 24.08$ to $72.32 \pm 19.46\left(\mathrm{ng} \cdot \mathrm{mL}^{-1} \cdot \mathrm{h}^{-1}\right)$ $\left(\mathrm{mL} \cdot \mathrm{min}^{-1}\right)(p<0.05)$. We conclude that there is no significant autoregulation of placental blood flow in the first hour after reduction in uterine driving pressure in the conscious pregnant rabbit. Uterine hypotension is associated with an increase in arterial pressure above the occluder and with the release of an inactive form of renin from the uterus. The significance of the latter two findings remains conjectural. (Pediatr Res 36: 102-110, 1994)
Abbreviations
aPRA, active plasma renin activity
tPRA, total plasma renin activity after activation with trypsin including the activity of both renin and prorenin $\mathbf{V}-\mathbf{A}$, venous concentration minus arterial concentration

the reduction in uterine driving pressure when a clamp is tightened around the distal aorta, and Berman et al. (1) observed a similar relationship in chronically catheterized conscious ewes when uterine arterial pressure was decreased by brief inflation of a balloon in the distal aorta. However, Venuto et al. (3) claimed that uteroplacental blood flow is autoregulated between 60 and 140 $\mathrm{mm} \mathrm{Hg}$ in anesthetized rabbits studied under a variety of conditions. This group of investigators also reported that there is a loss of autoregulation of placental blood flow in the anesthetized rabbit after administration of an inhibitor of the renin-angiotensin system (4).

We have previously shown that maternal placental blood flow in conscious rabbits is decreased in proportion to the decrease in uterine driving pressure after the administration of captopril, an angiotensin-converting enzyme inhibitor (5). It was not possible in that study to 
separate the effects of the reduced uterine driving pressure from specific effects resulting from inhibition of the renin-angiotensin system. The purpose of the present study was to study the effect of reduced uterine driving pressure alone on maternal placental blood flow. Chronically catheterized conscious rabbits were used to eliminate the effects of anesthesia. Uterine arterial blood pressure was reduced by means of pressure-controlled, computer-directed partial inflation of an occluder placed around the aorta below the renal arteries and above the ovarian arteries. This method reduced uterine arterial pressure in a way that did not also reduce the arterial pressure at the baroreceptors in the aortic arch, the carotid sinus, and the kidneys.

A secondary purpose of this study was to measure the effects of this procedure on upper-body blood pressure, because uterine ischemia has been postulated to be a cause of pregnancy-induced hypertension in humans and has been associated with an increase in arterial pressure in several animals (6-14). In addition, arterial and uterine vein samples were assayed for angiotensin I, aPRA, and tPRA for the purpose of measuring the uterine release of renin and angiotensin I after the hypotensive stimulus.

\section{METHODS}

Animals. Pregnant New Zealand White rabbits were purchased from a reliable commercial breeder. The does had been exposed to a male for $24 \mathrm{~h}$ on $\mathrm{d} 0$ of an expected 31- to 32-d gestation. They were brought to the animal care facility at 12-19 d, underwent surgery on d 24 or 25 , and were experimented on 3-5 d later. The animals were cared for in a facility accredited by the American Association of Laboratory Animal Care. All procedures were approved by the Institutional Animal Care and Use Committee at Oregon Health Sciences University and were done in accordance with the Guiding Principles for Research Involving Animals.

Surgery. Surgery was performed as previously described (5). Does were anesthetized with ketamine 60 $\mathrm{mg} / \mathrm{kg}$, xylazine $6 \mathrm{mg} / \mathrm{kg}$, and acepromazine $1.2 \mathrm{mg} / \mathrm{kg}$ given intramuscularly. An i.v. infusion of lactated Ringer's solution was given throughout the procedure. Additional i.v. doses of ketamine or xylazine were given as needed to maintain anesthesia, and lidocaine was used as a local anesthetic. Polyvinyl catheters $(1.0 \mathrm{~mm}$ inner diameter, $1.3 \mathrm{~mm}$ outer diameter) were placed into the femoral artery and advanced to the aortic bifurcation and into the right carotid artery and advanced into the left ventricle. A closed-end nylon catheter (Portex, Smith Industries Medical Systems, Wilmington, MA) was placed into the same carotid artery as was used for the left ventricular catheter, and the tip was advanced $7 \mathrm{~cm}$ to the arch of the aorta for measurement of upper-body arterial pressure. The left carotid artery was not disturbed. Two other closed-end nylon catheters were inserted into each of the femoral veins. A midline abdominal incision was then made, and the tip of each catheter was guided into the ipsilateral confluence of uterine veins of the left and right uterine horns approximately $7 \mathrm{~cm}$ from the ipsilateral iliac vein. After placement of all catheters, the doe was placed on her side. An incision was made in the left flank, and a $1-\mathrm{cm}$ section of the aorta below the renal arteries and above the ovarian arteries was freed from connective tissue. A Silastic inflatable occluder (In Vivo Metric, Healdsburg, CA) was tied around the aorta. The catheters and tube of the occluder were tunneled s.c. to an exit wound and were kept in a protective cup sutured to the back of the neck.

Experimental protocol. Studies were done $3-4 \mathrm{~d}$ postoperatively when the animals had resumed normal food intake. The rabbit was placed in a narrow box in which it was difficult to turn but was not restrained. The femoral artery, carotid artery, and one uterine vein catheter were attached to calibrated strain gauges (Spectramed, Oxnard, CA), and continuous measurements of pressure were made on a strip chart recorder (Gould Electronic, Cupertino, CA). Reference pressure was the atmospheric pressure at the bottom of the cage; we estimated that the right atrium of a resting rabbit is approximately $6.5 \mathrm{~cm}$ above cage bottom. A brief recording of the left ventricular pressure confirmed the correct placement of the catheter. The experiment was started after the animal appeared to be calm when the blood pressure and heart rate had been stable for at least $30 \mathrm{~min}$.

Control measurements were made of heart rate and blood pressure in the proximal aorta, the distal aorta, and the uterine vein. Samples were withdrawn simultaneously from the artery and both uterine veins after 3 times the catheter dead space was cleared. Two-mL samples were immediately placed into iced tubes containing NaEDTA and were immediately centrifuged in a cold room. The plasma was separated and frozen at $-20^{\circ} \mathrm{C}$ for later measurement of plasma renin activity. Additional 2-mL samples were collected anaerobically into heparinized syringes, placed immediately on ice, and analyzed for blood gas tensions and oxygen content. Cardiac output and organ blood flows were measured by means of radioactive microspheres injected into the left ventricle while a reference sample was withdrawn at a constant rate from the femoral artery. After collection of the reference sample, an additional $1 \mathrm{~mL}$ was drawn from the catheter to demonstrate that all microspheres were cleared by the end of the sampling period. The occluder was then partially inflated to reduce the pressure in the distal aorta to the desired level. This pressure was held for about $1 \mathrm{~h}$ by computer servo control of the degree of inflation of the occluder. Samples were obtained, and the measurements made in the control period were repeated at $1 \mathrm{~h}$.

Servo control of distal aortic blood pressure. The occluder was attached to a modified roller pump (Gilson, Middleton, WI) that could inject or withdraw fluid from the occluder tubing. The pressure transducer was coupled to the polygraph, which was interfaced with the computeroperated data acquisition and control system (Hewlett- 
Packard 3479A, Hewlett-Packard, Palo Alto, CA). The output voltage of the polygraph was digitized and compared with the voltage associated with the target blood pressure. The computer (Hewlett-Packard 9826) directed the pump to inflate or deflate the occluder according to the deviation of actual blood pressure from desired blood pressure. The size of the correction made by the computer-driven pump varied according to the magnitude of the deviation from the target pressure. Small deviations resulted in smaller corrections to avoid overcorrection. Details of the system have been previously published (15-17).

Analytical techniques. Arterial blood samples were analyzed for $\mathrm{pH}, \mathrm{PCO}_{2}$, and $\mathrm{Po}_{2}$ on a calibrated blood gas analyzer (Radiometer MK2, The London Company, Cleveland, $\mathrm{OH})$. Arterial and uterine venous samples were analyzed in triplicate for oxygen content $\left(\right.$ Lex- $\mathrm{O}_{2}$ Con, Hospex, Chestnut Hill, MA).

The aPRA in arterial and uterine venous samples was measured in duplicate as the rate of angiotensin I generation in plasma incubated at $37^{\circ} \mathrm{C}$. Angiotensin $\mathrm{I}$ was measured by RIA (Rianen, Dupont, Billerica, MA). The assay was standardized against Medical Research Council Standard A code 71/328. The interassay coefficient of variation was $11.9 \%$. Circulating angiotensin I concentration was determined from the control sample held at $4^{\circ} \mathrm{C}$.

tPRA was determined by activation of the plasma with trypsin before renin activity measurement according to Hsueh et al. (18). Recrystallized trypsin, 10000 benzoyl arginine ethyl ester U/mg (Sigma Chemical Co., St. Louis, MO), in pH 7.5 buffer was added to plasma samples at $0^{\circ} \mathrm{C}$ to give a final concentration of $1 \mathrm{mg}$ of trypsin per $\mathrm{mL}$. The reaction was stopped after $30 \mathrm{~min}$ with lima bean-soybean trypsin inhibitor (Sigma Chemical Co.) that had been freshly dissolved in pH 7.5 buffer. Trypsin inhibitor was added in the same quantity as trypsin. Angiotensin I was measured before and after the trypsinactivated plasma was incubated at $37^{\circ} \mathrm{C}$. Because renin and angiotensinogen may be partially degraded by trypsin, we chose not to calculate the activity activated by trypsin incubation as the difference between tPRA and aPRA.

Blood flow measurements. Cardiac output and organ blood flows were then measured with $15-\mu \mathrm{m}$ diameter radioactive microspheres (New England Nuclear, Boston, MA). Two of the following isotopes were used in random order: ${ }^{141} \mathrm{Ce},{ }^{51} \mathrm{Cr},{ }^{95} \mathrm{Nb},{ }^{46} \mathrm{Sc}$, and ${ }^{85} \mathrm{Sr}$. The spheres were mixed in $6 \%$ dextran (McGaw, Irvine, CA) and deaggregated by forcing the suspension three or more times through a 25-gauge needle. Deaggregation was occasionally checked by inspection of a drop of injectate under the microscope. Well-mixed spheres were injected into the left ventricle while a reference sample was withdrawn from the femoral artery catheter over at least 2 min $(19,20)$. An additional $1 \mathrm{~mL}$ was then withdrawn. In no case was the radioactivity in the second syringe greater than $1 \%$ of the radioactivity in the sample syringe, which confirmed that the withdrawal period was of sufficient duration to sample circulating spheres until essentially all spheres had been trapped. Adequate mixing of microspheres was confirmed by comparing right and left kidney blood flows $\left(4.79 \pm 0.37\right.$ vs $4.64 \pm 0.34 \mathrm{~mL} \cdot \mathrm{min}^{-1} \cdot \mathrm{g}^{-1}$; NS). Individual kidney flows in the same injection did not differ by more than $10 \%$ (the absolute value of the difference averaged $4.5 \pm 1.3 \%)$ and were highly correlated $(p$ $<0.001)$.

Simultaneous injections of $15-\mu \mathrm{m}$ and $25-\mu \mathrm{m}$ microspheres were made in three of the rabbits included in this study to check for possible shunting of the smaller microspheres through the placental vasculature (21). There was no difference in cardiac output measured with the two different sizes. The values for placental blood flow were also identical: $4.10 \pm 0.13$ vs $4.04 \pm 0.12 \mathrm{~mL} / \mathrm{min}$ per placenta for $15 \mu \mathrm{m} v s 25 \mu \mathrm{m}$ in the control period. There was also no difference in placental blood flow measured with either size of microspheres after inflation of the occluder. There was a strong correlation between flows measured with the two microspheres $(r=0.96, p<$ $0.001)$. That there was no difference in placental shunting of $15-\mu \mathrm{m}$ and $25-\mu \mathrm{m}$ microspheres in pregnant rabbits is in agreement with previously published results (22). However, myoendometrial flow measured with $15-\mu \mathrm{m}$ microspheres was $30 \%$ less than when measured with $25-\mu \mathrm{m}$ microspheres in both the control and the reduced uterine driving pressure periods. This is consistent with previous results that showed that myoendometrial trapping of $15-\mu \mathrm{m}$ spheres was $30 \%$ less than that of $25-\mu \mathrm{m}$ spheres and that the shunt fraction did not increase when maternal arterial pressure was lowered with prostaglandin $I_{2}(22)$. The uncorrected values for the blood flows measured with $15-\mu \mathrm{m}$ microspheres are reported below.

Autopsy. Animals were killed with an i.v. injection of a commercial euthanasia solution. As soon as the mother ceased breathing, the abdomen was opened. The uterus was incised, and the fetuses were inspected. They were considered alive only if gasping or kicking was noted. If they were dead, the time of death was estimated from the degree of maceration. Live fetuses usually ceased breathing shortly after delivery. If they did not, they were killed with an additional dose of euthanasia solution given intraperitoneally. The positions of all catheters were confirmed. The doe's kidneys, fetuses, placentas, and both uterine horns were separated and weighed. All blood samples and tissues were then washed and prepared for microsphere isotope counting in a gamma scintillation spectrometer (Packard Instruments, Downers Grove, IL) with a multichannel analyzer (Nuclear Data, Livermore, CA). Isotope counts were separated by means of a least squares spectrum fitting routine.

Calculations. Blood flows were calculated as the product of the reference blood flow and the ratio of radioactivity $(\mathrm{cpm})$ in the tissue to the radioactivity $(\mathrm{cpm})$ in the reference sample (20). Tissue vascular resistance was calculated as the ratio of driving pressure (difference between the appropriate arterial and venous pressure) to the tissue blood flow. Systemic vascular resistance was 
calculated as the reciprocal of the sum of the separately calculated conductances of the upper and lower body (above and below the level of the occluder).

Oxygen delivery to the uterine horn was calculated as the product of total uteroplacental blood flow per uterine horn $(F)$ and arterial oxygen content $\left(C_{A}\right)$. Uterine oxygen consumption $\left(\dot{\mathrm{VO}}_{2}\right)$ of each horn was calculated according to Fick's principle as the product of uteroplacental blood flow per horn $(F)$ and the corresponding uterine arteriovenous difference in oxygen content $\left(\mathrm{C}_{\mathrm{A}-\mathrm{V}}\right)$. Uterine oxygen extraction was calculated as the ratio of the uterine arteriovenous difference for oxygen and arterial oxygen content $\left(\mathrm{C}_{\mathrm{A}-\mathrm{v}} / \mathrm{C}_{\mathrm{A}}\right)$ and expressed as a percentage.

Plasma flow was calculated as the product of the blood flow (F) and the plasma fraction of the blood $(1-$ hct $)$.

The net uterine release (or uptake) rate of angiotensin I was calculated as the product of uterine plasma flow and the venoarterial concentration difference for angiotensin I.

By analogy, the net uterine release rate (ن்) of total or active renin activity was calculated as the product of the venoarterious difference for the appropriate activity $\left(\right.$ PRA $\left._{v-\mathrm{a}}\right)$ and plasma flow $(5,23)$ :

$$
\dot{\mathrm{U}}=\left(\mathrm{PRA}_{\mathrm{v}-\mathrm{a}}\right)(\mathrm{F})(1-\mathrm{hct}),\left(\mathrm{ng} \cdot \mathrm{mL}^{-1} \cdot \mathrm{h}^{-1}\right)\left(\mathrm{mL} \cdot \mathrm{min}^{-1}\right)
$$

Data were not available for all horns. Therefore, calculations for uterine oxygen consumption and uterine renin production were done for each separate uterine horn where adequate data were available. Because of the extreme variation in size and numbers of fetuses in opposite horns even within a single rabbit, no attempt was made to estimate results for a horn based on the results of the contralateral horn. Values for the individual horns were averaged, but the degrees of freedom for statistical testing were based on the number of rabbits and not on the number of uterine horns.

The ratio of the relative change in flow $(F)$ and the relative change in driving pressure $(\mathrm{P})$ was calculated to test how well blood flow was preserved after reduction in perfusion pressure.

$$
\mathrm{R}=\left[\left(\mathrm{F}_{1}-\mathrm{F}_{2}\right) / \mathrm{F}_{1}\right] /\left[\left(\mathrm{P}_{1}-\mathrm{P}_{2}\right) / \mathrm{P}_{1}\right]
$$

An index of zero indicates perfect preservation of flow with changes in pressure, an index of one indicates no regulation, and an index between zero and one indicates some regulation.

Statistical procedures. Results are reported as mean \pm SEM unless otherwise stated. A priori comparisons of measurements made in the control and reduced pressure periods were made by paired $t$ test. Analysis of variance for repeated measures was used for changes in upper- and lower-body blood pressure after inflation of the occluder. Results obtained during the experimental periods were compared with control values by Dunnett's test. Methods were based on tose of Winer (24).

\section{RESULTS}

Ten pregnant does were studied under the protocol described above. They weighed $4.1 \pm 0.1 \mathrm{~kg}$. Surgery was performed on d $24.6 \pm 0.3$ of gestation. They were studied $3-4 \mathrm{~d}$ postoperatively at $27-29 \mathrm{~d}$ of gestation. There were 94 fetuses implanted; 56 were definitely alive at the end of the study. The mean weight of the live fetuses was $27.2 \pm 0.8 \mathrm{~g}$; their placentas weighed $5.4 \pm$ $0.2 \mathrm{~g}$. Seventeen fetuses were severely macerated and were judged to have been dead before the operation. One doe had fetuses implanted in only one horn, and one doe had a congenitally absent kidney and uterine horn on the left side. The latter doe's blood pressure, cardiac output, kidney weight, total renal blood flow, myoendometrial blood flow, and placental blood flow normalized for tissue weight were all close to the mean values for the entire group.

Blood pressure was recorded for at least $30 \mathrm{~min}$ before control measurements were made. The occluder was then partially inflated and repeat measurements were made $54 \pm 4$ min later. The mean blood volume withdrawn for each set of samples and microsphere determinations was $23 \pm 1 \mathrm{~mL}$ (approximately $6.5 \%$ of estimated blood volume). Arterial blood gas tensions, hematocrits, and arterial and uterine venous oxygen contents are shown in Table 1. There were no differences in arterial $\mathrm{pH}, \mathrm{PO}_{2}$, or oxygen content before and after reduction of lower aortic blood pressure, but $\mathrm{PCO}_{2}$ decreased approximately $10 \%(p<0.05)$. The decrease in hematocrit from 35.1 to $33.4 \%(p<0.05)$ was consistent with the estimated volume of blood withdrawn.

Heart rates, upper- and lower-body arterial blood pressures and uterine venous blood pressure are summarized in Table 2. The time course of changes in upper- and lower-body arterial blood pressure is shown in Figure 1. Upper-body blood pressure was available for only seven does; one animal did not have a carotid artery catheter placed and two catheters were occluded by blood clots. The control mean upper-body arterial pressure corrected

Table 1. Maternal arterial hematocrit and blood gas tensions at $39^{\circ} \mathrm{C}$ and arterial and uterine venous oxygen contents before and after reduction of uterine driving pressure by inflation of occluder placed around aorta between renal arteries and ovarian arteries*

\begin{tabular}{lllllc}
\hline & Units & $n$ & Control & $\begin{array}{l}\text { Reduced } \\
\text { pressure }\end{array}$ & $p$ \\
\hline $\begin{array}{llllll}\text { Arterial } \\
\mathrm{pH}\end{array}$ & & & $7.42 \pm 0.01$ & $7.44 \pm 0.01$ & $\mathrm{NS}$ \\
$\mathrm{PcO}_{2}$ & torr & 10 & $32.5 \pm 1.2$ & $29.3 \pm 1.1$ & $<0.05$ \\
& $\mathrm{kPa}$ & & $4.33 \pm 0.16$ & $3.91 \pm 0.15$ & \\
$\mathrm{Po}_{2}$ & torr & 10 & $88.3 \pm 1.9$ & $89.1 \pm 1.1$ & $\mathrm{NS}$ \\
& $\mathrm{kPa}$ & & $11.8 \pm 0.3$ & $11.9 \pm 0.1$ & \\
$\mathrm{Hematocrit}$ & $\%$ & 10 & $35.1 \pm 1.5$ & $33.4 \pm 1.0$ & $<0.05$ \\
{$\left[\mathrm{o}_{2}\right]$} & $\mathrm{mL} / \mathrm{dL}$ & 10 & $14.9 \pm 0.6$ & $14.4 \pm 0.4$ & $\mathrm{NS}$ \\
& $\mathrm{mmol} / \mathrm{L}$ & & $6.6 \pm 0.3$ & $6.4 \pm 0.2$ & \\
Uterine vein $\left[\mathrm{o}_{2}\right]$ & $\mathrm{mL} / \mathrm{dL}$ & 10 & $7.5 \pm 0.9$ & $6.0 \pm 0.6$ & $<0.05$ \\
& $\mathrm{mmol} / \mathrm{L}$ & & $3.4 \pm 0.4$ & $2.7 \pm 0.3$ & \\
\hline
\end{tabular}

\footnotetext{
${ }^{*} n=14$ uterine horns in 10 pregnant does. Values are mean \pm SEM.
} 
Table 2. Hemodynamic variables before and $1 \mathrm{~h}$ after inflation of occluder around distal aorta of 10 pregnant rabbits*

\begin{tabular}{|c|c|c|c|c|}
\hline & $n$ & Control & $\begin{array}{l}\text { Reduced } \\
\text { pressure }\end{array}$ & $p$ \\
\hline Heart rate (bpm) & 10 & $273 \pm 9$ & $283 \pm 10$ & $<0.05$ \\
\hline \multicolumn{5}{|l|}{ Blood pressure $\dagger(\mathrm{mm} \mathrm{Hg})$} \\
\hline Carotid artery & 7 & $86 \pm 5$ & $98 \pm 6$ & $<0.01$ \\
\hline Femoral artery & 10 & $83 \pm 5$ & $65 \pm 4$ & $<0.001$ \\
\hline Uterine vein & 10 & $7 \pm 1$ & $7 \pm 1$ & NS \\
\hline \multicolumn{5}{|l|}{ Blood flows } \\
\hline $\begin{array}{l}\text { Cardiac output } \\
\mathrm{mL} \cdot \mathrm{min}^{-1} \\
\mathrm{~mL} \cdot \mathrm{min}^{-1} \cdot \mathrm{kg}^{-1}\end{array}$ & 9 & $\begin{array}{l}839 \pm 78 \\
214 \pm 24\end{array}$ & $\begin{array}{l}814 \pm 64 \\
206 \pm 18\end{array}$ & NS \\
\hline \multicolumn{5}{|l|}{ Upper body } \\
\hline $\begin{array}{l}\mathrm{mL} \cdot \min ^{-1} \\
\mathrm{~mL} \cdot \min ^{-1} \cdot 100 \mathrm{~g}^{-1}\end{array}$ & 9 & $\begin{array}{c}651 \pm 62 \\
31.9 \pm 4.0\end{array}$ & $\begin{array}{l}671 \pm 55 \\
32.3 \pm 3.0\end{array}$ & NS \\
\hline \multicolumn{5}{|l|}{ Kidneys } \\
\hline $\begin{array}{l}\mathrm{mL} \cdot \min ^{-1} \\
\mathrm{~mL} \cdot \min ^{-1} \cdot 100 \mathrm{~g}^{-1}\end{array}$ & 9 & $\begin{array}{l}111 \pm 14 \\
454 \pm 56\end{array}$ & $\begin{array}{l}104 \pm 8 \\
423 \pm 31\end{array}$ & NS \\
\hline \multicolumn{5}{|l|}{ Lower body } \\
\hline $\begin{array}{l}\mathrm{mL} \cdot \mathrm{min}^{-1} \\
\mathrm{~mL} \cdot \mathrm{min}^{-1} \cdot 100 \mathrm{~g}^{-1}\end{array}$ & 9 & $\begin{array}{c}188 \pm 18 \\
10.2 \pm 1.1\end{array}$ & $\begin{array}{l}143 \pm 14 \\
7.7 \pm 0.8\end{array}$ & $<0.05$ \\
\hline \multicolumn{5}{|l|}{ Hindquarters } \\
\hline $\begin{array}{l}\mathrm{mL} \cdot \min ^{-1} \\
\mathrm{~mL} \cdot \mathrm{min}^{-1} \cdot 100 \mathrm{~g}^{-1}\end{array}$ & 9 & $\begin{aligned} 153 & \pm 15 \\
10.0 & \pm 1.1\end{aligned}$ & $\begin{array}{l}116 \pm 11 \\
7.5 \pm 0.8\end{array}$ & $<0.05$ \\
\hline \multicolumn{5}{|l|}{$\begin{array}{l}\text { Vascular resistances } \\
\qquad\left(\mathrm{mm} \mathrm{Hg} \cdot \mathrm{min} \cdot \mathrm{mL}^{-1}\right)\end{array}$} \\
\hline Systemic & 7 & $0.086 \pm 0.010$ & $0.093 \pm 0.006$ & NS \\
\hline Upper body & 7 & $0.112 \pm 0.013$ & $0.124 \pm 0.009$ & NS \\
\hline Lower body & 9 & $0.420 \pm 0.050$ & $0.431 \pm 0.053$ & NS \\
\hline Kidneys & 7 & $0.739 \pm 0.100$ & $0.857 \pm 0.062$ & NS \\
\hline Hindquarters & 9 & $0.514 \pm 0.060$ & $0.537 \pm 0.072$ & NS \\
\hline
\end{tabular}

* Values are mean \pm SEM.

† Referenced to cage bottom, $6.5 \mathrm{~cm}$ below right atrial level.

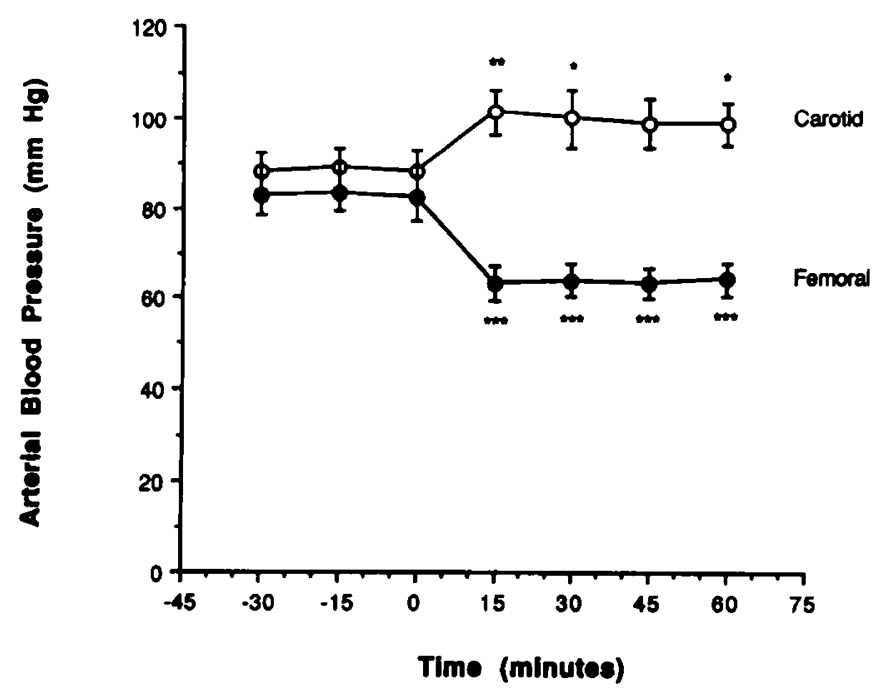

Figure 1. Time course of mean \pm SEM arterial blood pressures above (carotid, $n=7$ ) and below (femoral, $n=10$ ) the level of the aortic occluder placed between the renal and ovarian arteries in pregnant does. Asterisks indicate statistical significance compared with control $(-30,-15$, and $0 \mathrm{~min}):^{*}, p<0.05 ;^{* *}, p<0.01$; and ${ }^{* * *}, p<0.001$. Zero pressure is cage bottom; estimated right atrial level is $6.5 \mathrm{~cm}$ above cage bottom.

to estimated right atrial level was $79 \mathrm{~mm} \mathrm{Hg}$. For the seven animals with functioning carotid artery catheters, mean control arterial pressure was $2.6 \pm 1.5 \mathrm{~mm} \mathrm{Hg}$ higher in the upper body than the lower body (NS). After the occluder was inflated, lower-body arterial blood pressure decreased $22 \pm 3 \%$ from the control value $\left(F_{6,54}=\right.$ $36.7, p<0.001)$, and upper-body blood pressure increased $14 \pm 5 \%\left(F_{6,36}=4.83, p<0.01\right)$. There was no apparent relationship between the magnitude of the decrease in lower-body arterial pressure and the magnitude of the increase in upper-body blood pressure.

Cardiac output and regional blood flows are summarized in Table 2 for nine does. One animal was accidentally contaminated externally with radioactive microspheres, so that whole-body blood flows could not be calculated. There were no changes in cardiac output, blood flow to the upper body, or renal blood flow after inflation of the occluder. Blood flow to the lower body was decreased by $24 \pm 9 \%$ from the control value $(p<$ $0.05)$. Blood flow to the hindquarters fell $23 \pm 7 \%(p<$ $0.05)$. There were no changes in the resistances to blood flow to these tissues (Table 2). The percentage of microspheres carried to the lungs during the two microsphere injections was $5 \pm 1 v s 7 \pm 2 \%$ (NS).

Changes in uterine tissue blood flows are shown in Table 3. Combined uteroplacental blood flow for both horns of the uterus was approximately $4 \%$ of cardiac output and $20 \%$ of the blood flow to the body below the occluder. Results for total uterine, myoendometrial, and placental blood flow are reported for 13 of the 17 horns in

Table 3. Uteroplacental blood flows, vascular resistances, and uterine oxygen consumption before and after reduction of uterine driving pressure to 13 pregnant horns*

\begin{tabular}{|c|c|c|c|c|}
\hline & $n$ & Control & $\begin{array}{l}\text { Reduced } \\
\text { pressure }\end{array}$ & $p$ \\
\hline \multicolumn{5}{|l|}{ Total blood flows } \\
\hline $\begin{array}{l}\text { Combined uteroplacental } \\
\mathrm{mL} \cdot \min ^{-1} \\
\mathrm{~mL} \cdot \min ^{-1} \cdot 100 \mathrm{~g}^{-1} \dagger\end{array}$ & 13 & $\begin{array}{l}17.7 \pm 1.9 \\
12.4 \pm 1.1\end{array}$ & $\begin{array}{r}12.9 \pm 1.4 \\
8.7 \pm 0.8\end{array}$ & $<0.02$ \\
\hline $\begin{array}{l}\text { Myoendometrium } \\
\mathrm{mL} \cdot \mathrm{min}^{-1} \\
\mathrm{~mL} \cdot \mathrm{min}^{-1} \cdot 100 \mathrm{~g}^{-1}\end{array}$ & 13 & $\begin{array}{r}4.0 \pm 0.3 \\
17.3 \pm 1.6\end{array}$ & $\begin{array}{r}3.5 \pm 0.5 \\
13.9 \pm 1.9\end{array}$ & NS \\
\hline $\begin{array}{l}\text { Placental } \ddagger \\
\mathrm{mL} \cdot \min ^{-1} \\
\mathrm{~mL} \cdot \min ^{-1} \cdot 100 \mathrm{~g}^{-1}\end{array}$ & 13 & $\begin{array}{l}13.0 \pm 1.9 \\
73.8 \pm 0.4\end{array}$ & $\begin{aligned} 8.9 & \pm 1.2 \\
53.4 & \pm 0.42\end{aligned}$ & $<0.01$ \\
\hline \multicolumn{5}{|l|}{ Placental blood flow $\ddagger$} \\
\hline Per placenta $\left(\mathrm{mL} \cdot \mathrm{min}^{-1}\right)$ & 49 & $3.87 \pm 0.24$ & $2.77 \pm 0.22$ & $<0.001$ \\
\hline $\begin{array}{l}\text { Per gram placenta } \\
\qquad\left(\mathrm{mL} \cdot \min ^{-1} \cdot \mathrm{g}^{-1}\right)\end{array}$ & 49 & $0.738 \pm 0.040$ & $0.534 \pm 0.042$ & $<0.001$ \\
\hline $\begin{array}{l}\text { Per gram fetus } \\
\qquad\left(\mathrm{mL} \cdot \min ^{-1} \cdot \mathrm{g}^{-1}\right)\end{array}$ & 49 & $0.145 \pm 0.007$ & $0.102 \pm 0.007$ & $<0.001$ \\
\hline $\begin{array}{l}\text { Per gram conceptus } \\
\qquad\left(\mathrm{mL} \cdot \mathrm{min}^{-1} \cdot \mathrm{g}^{-1}\right)\end{array}$ & 49 & $0.121 \pm 0.006$ & $0.086 \pm 0.006$ & $<0.001$ \\
\hline $\begin{array}{l}\text { Vascular resistances } \\
\qquad\left(\mathrm{mm} \mathrm{Hg} \cdot \mathrm{min} \cdot \mathrm{mL}^{-1}\right)\end{array}$ & 13 & $4.70 \pm 0.58$ & $4.98 \pm 0.54$ & NS \\
\hline Myoendometrium & 13 & $19.10 \pm 1.44$ & $19.20 \pm 1.98$ & NS \\
\hline \multicolumn{5}{|l|}{$\begin{array}{l}\text { Oxygen consumption per } \\
\text { horn }\end{array}$} \\
\hline $\begin{array}{l}\mathrm{mL} / \mathrm{min} \\
\mu \mathrm{mol} / \mathrm{min}\end{array}$ & 13 & $\begin{array}{l}1.15 \pm 0.16 \\
51.3 \pm 7.1\end{array}$ & $\begin{array}{l}1.06 \pm 0.13 \\
47.3 \pm 5.8\end{array}$ & \\
\hline
\end{tabular}

* Values are mean \pm SEM.

† Combined weight of myoendometrium, placentas, and fetuses excluding weight of extrafetal fluids.

$\ddagger$ Placentas of live fetuses only. 
which fetuses were implanted in the nine does in which microsphere measurements were made. In the four horns that were excluded, fewer than $50 \%$ of the fetuses that were probably alive at the time of surgery could be confirmed to have survived until the end of the experiment. For all horns, the flow to the placentas of dead fetuses was $<5 \%$ of total placental blood flow. (When the data were analyzed to include all placentas from all horns, the statistical significance of conclusions about changes in blood flow were not altered.) The combined blood flow to the myoendometrium and placentas decreased $24 \pm 8 \%$ from $17.7 \pm 1.9$ to $12.9 \pm 1.4 \mathrm{~mL} / \mathrm{min}$ for 13 horns $(p<0.02)$. There was no apparent relationship between control driving pressure and control placental blood flow even when normalized for placental or fetal weight. After the $22 \pm 2 \%$ reduction in uterine driving pressure, there was a $27 \pm 6 \%$ reduction in total maternal placental blood flow of the live fetuses from $13.0 \pm 1.9$ to $8.9 \pm 1.2 \mathrm{~mL} / \mathrm{min}(p<0.01)$. There was a slight but statistically insignificant reduction in flow to the myoendometrium $(4.0 \pm 0.3 v s 3.5 \pm 0.5 \mathrm{~mL} / \mathrm{min})$. There was no change in the fraction of total uterine blood flow distributed to the live placentas $(68 \pm 4 v s 66 \pm 4 \%$; NS). There were no statistically significant changes in the resistances to blood flow of either the placental or myoendometrial tissues (Table 3).

The relationship between the change in blood pressure and the change in placental blood flow is shown for 13 horns in Figure 2. In all but one case, blood flow to live placentas fell, approximately in proportion to the decrease in placenta driving pressure. The mean ratio of the change in live placental flow and the change in driving pressure was $1.30 \pm 0.28$. This ratio was not significantly different from 1 but was highly significantly different from $0(p<0.001)$, indicating that there was no evidence for regulation of maternal placental blood flow. The mean

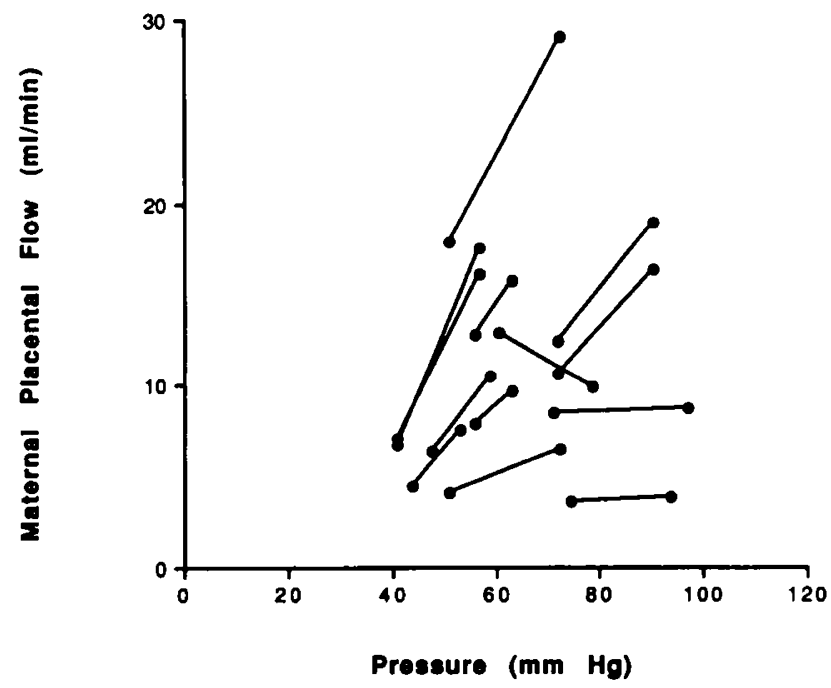

Figure 2. The lines connect pairs of observations for uterine driving pressure and maternal placental flow (combined flow for all live placentas) for 13 pregnant uterine horns in nine does. The higher pressure is the control value. ratio for the entire uterine horn was $1.17 \pm 0.33$, which was also not significantly different from 1 but was significantly different from $0(p<0.01)$. The mean ratio for the myoendometrium was $0.69 \pm 0.50$, which was not significantly different from either 1 or 0 ; this value is compatible with some regulation of myoendometrial flow. By comparison, the ratio was $1.12 \pm 0.35$ for the hindquarters, which is significantly different from zero $(n=9, p<$ 0.05 ).

As total uterine blood flow decreased, uterine oxygen consumption ( $n=13$ horns) was essentially unchanged (1.15 \pm 0.16 vs $1.06 \pm 0.13 \mathrm{~mL} / \mathrm{min}$; NS), although uterine oxygen delivery decreased from $2.56 \pm 0.28$ to $1.85 \pm 0.22 \mathrm{~mL} / \mathrm{min}(p<0.01)$. Oxygen extraction increased from $48 \pm 6$ to $58 \pm 5 \%(p<0.05)$.

After reduction in lower aortic pressure, there was no change in circulating arterial angiotensin I concentration or in aPRA (Table 4). There was an increase in arterial tPRA. There were no significant differences between the uterine venous and arterial plasma angiotensin I concentrations or those of aPRA during the control period or after reduction of uterine arterial pressure (Table 4). Although there was no statistically significant V-A difference for tPRA in the control period, there was a significant V-A difference after uterine perfusion pressure was reduced. Although uterine plasma flow was decreased, the V-A difference increased so much that there was a statistically demonstrable net uterine release rate of tPRA after the reduction in uterine artery pressure. Because there was no demonstrable net release of aPRA, this result implies that there was an increase in the net release rate of inactive renin from the uterus during the period of reduced pressure and flow.

\section{DISCUSSION}

The major purpose of this study was to investigate the effect of reduced uterine driving pressure on maternal placental blood flow in the unanesthetized animal. By reducing pressure by mechanical means, there was no confounding chemical rather than autoregulatory vasodilation of the placental vasculature and no hypotensive stimulus to the kidneys or to the carotid and aortic baroreceptors. Instead, upper-body blood pressure increased about $15 \%$. Although heart rate and upper-body arterial pressure did not remain constant after inflation of the occluder, the disturbances seen in this study were minor in comparison to those induced by other possible methods for reducing uterine driving pressure. We conclude that the reduction in maternal placental blood flow that occurred in these experiments was largely the direct result of the reduction in uterine driving pressure.

In this study, the reduction in placental flow was roughly in proportion to the reduction in uterine driving pressure. Our findings are not compatible with any substantial autoregulation of maternal placental blood flow in rabbits and are similar to the previously reported relationship between uterine driving pressure and combined 
Table 4. Arterial angiotensin I concentration (AI), tPRA, aPRA, uterine $V$-A difference, and uterine release rate (product of concentration or activity and uterine plasma flow) before and after reduction of uterine arterial blood pressure*

\begin{tabular}{|c|c|c|c|c|}
\hline & $n$ & Control & Reduced pressure & $p$ \\
\hline \multicolumn{5}{|l|}{ Circulating arterial } \\
\hline $\mathrm{AI}\left(\mathrm{ng} \cdot \mathrm{mL}^{-1}\right)$ & 10 & $2.95 \pm 1.07$ & $1.46 \pm 0.59$ & NS \\
\hline tPRA (ng $\left.\cdot \mathrm{mL}^{-1} \cdot \mathrm{h}^{-1}\right)$ & 10 & $20.24 \pm 2.39$ & $27.34 \pm 5.33$ & $<0.05$ \\
\hline $\operatorname{aPRA}\left(\mathrm{ng} \cdot \mathrm{mL}^{-1}\right)$ & 10 & $8.83 \pm 3.72$ & $10.70 \pm 5.56$ & NS \\
\hline \multicolumn{5}{|l|}{ Uterine V-A difference } \\
\hline $\mathrm{AI}\left(\mathrm{ng} \cdot \mathrm{mL}^{-1}\right)$ & 14 & $-1.93 \pm 0.88$ & $-0.34 \pm 0.56$ & NS \\
\hline tPRA (ng $\left.\cdot \mathrm{mL}^{-1} \cdot \mathrm{h}^{-1}\right)$ & 14 & $2.88 \pm 2.51$ & $12.51 \pm 4.26$ & $<0.05$ \\
\hline aPRA (ng $\left.\cdot \mathrm{mL}^{-1} \cdot \mathrm{h}^{-1}\right)$ & 14 & $0.85 \pm 0.99$ & $0.23 \pm 1.01$ & NS \\
\hline \multicolumn{5}{|l|}{ Uterine release rate per horn } \\
\hline $\mathrm{AI}\left(\mathrm{ng} \cdot \mathrm{mL}^{-1}\right)$ & 13 & $-20.82 \pm 11.31$ & $-3.75 \pm 4.32$ & NS \\
\hline IPRA (ng $\left.\cdot \mathrm{mL}^{-1} \cdot \mathrm{h}^{-1}\right)\left(\mathrm{mL} \cdot \mathrm{min}^{-1}\right)$ & 13 & $31.66 \pm 24.08$ & $72.32 \pm 19.46$ & $<0.05$ \\
\hline aPRA $\left(\mathrm{ng} \cdot \mathrm{mL}^{-1} \cdot \mathrm{h}^{-1}\right)\left(\mathrm{mL} \cdot \mathrm{min}^{-1}\right)$ & 13 & $8.94 \pm 11.52$ & $3.49 \pm 6.58$ & NS \\
\hline
\end{tabular}

* Values are mean $\pm \mathrm{SEM}$.

uteroplacental blood flow in anesthetized pregnant sheep $(1,2)$. The conclusion that there is no substantial autoregulation of maternal placental blood flow in conscious rabbits is strengthened by the fact that a $15 \%$ increase in carotid artery pressure should have caused, if anything, a baroreceptor reflex-mediated reduction in peripheral vascular resistance in addition to any reduction in placental resistance that might have occurred as a result of autoregulation.

Our results differ from results of a study on anesthetized pregnant rabbits by Venuto et al. (3) where there was apparent autoregulation of uteroplacental flo:v with as much as a $30-35 \%$ reduction in maternal arterial pressure from 95 to $60-65 \mathrm{~mm} \mathrm{Hg}$. This contrasts with a $27 \pm$ $6 \%$ reduction in maternal placental flow found after a 22 $\pm 2 \%$ reduction in lower aortic blood pressure from a mean of 76 to $58 \mathrm{~mm} \mathrm{Hg}$ in the present study.

There are important differences between the two studies in rabbits. One is that the range of uterine driving pressures in the present study included only normal control pressures for conscious pregnant rabbits as defined by Brown and Venuto (25) and subnormal blood pressures, as opposed to extreme supranormal blood pressures as seen in the anesthetized rabbits (3). Another is that uterine arterial pressure was reduced mechanically in the present study rather than by chemical vasodilators. Finally, and perhaps most importantly, the present study was concerned with maternal placental blood flow, in contrast with combined uteroplacental blood flow as in the previous study. Because maternal placental blood flow represents the majority of combined uteroplacental flow, changes in uteroplacental blood flow are often thought to reflect changes in placental blood flow alone. This is not necessarily true, particularly at supranormal pressures or with the use of vasodilators in the face of circulating vasoconstrictors, as was shown by a recent study in chronically catheterized sheep (26).

Ferris and Weir (4) have suggested that autoregulation of uteroplacental blood flow in the rabbit depends on a specific renin-angiotensin system, because uteroplacental flow decreases after administration of captopril or saralasin to the doe. We found that captopril administra- tion (Fig. 2 in ref. 5) and inflation of an occluder around the distal aorta (Fig. 2 in present study) resulted in similar decreases in maternal placental blood flow for similar reductions in uterine driving pressure. After captopril, the ratio of proportional change in maternal placental flow to the proportional change in uterine driving pressure was $0.97 \pm 48$ over approximately the same range of pressure reduction in the present study. Thus, we cannot confirm the hypothesis that the renin-angiotensin system specifically supports placental blood flow.

It is not possible at this time to precisely determine the shape of the curve describing the relationship between uterine driving pressure and maternal placental flow largely because of the technical limitations of microsphere flow measurements. However, this is the only currently available technique that can satisfactorily separate placental and myoendometrial flows. Because there is a $5-10 \%$ error in the flow measurement intrinsic to the statistical distribution of the spheres, the technique limits the possibility of detecting significant changes in maternal placental blood flow when there is only a small reduction in uterine driving pressure. We therefore chose to study a range of pressure reductions from 10 to $30 \%$. It is not possible to conclude from this study that there is no autoregulation of placental blood in the range of $0-10 \%$ reduction in uterine driving pressure, but it is possible to conclude that the range of any autoregulation must be small. The most parsimonious explanation consistent with our results is that a reduction in uterine driving pressure results in a reduction of maternal placental blood flow of a similar magnitude.

Upper-body blood pressure increased significantly in this study after inflation of the distal aortic occluder. A similar result has been found in conscious pregnant (but not nonpregnant) dogs (13), although the direct hemodynamic effects of lower aortic obstruction in pregnant and nonpregnant animals are not directly comparable because of the greater lower-body blood flow associated with the pregnant uterus. A review of our polygraph records showed that carotid arterial pressure did not increase immediately, i.e. within 1 min after inflation of the occluder, as might be expected from a direct mechan- 
ical effect of tightening the occluder around the aorta. However, carotid artery pressure was increased at approximately $5 \mathrm{~min}$. This time course would be consistent with slight autoregulatory vasoconstriction of upperbody tissues, subsequent to a redirection of aortic flow. Interpretation of this finding is confused by the fact that some does seemed to be slightly disturbed by occluder inflation. We have not observed any behavioral change during other procedures such as microsphere injection. Although the animals returned to their usual resting state within a few minutes, the small but consistent elevation in heart rate $1 \mathrm{~h}$ after inflation of the occluder may have signified persistent mild discomfort that also produced a modest rise in arterial pressure. The fact that the increase in blood pressure in pregnant dogs can be blocked with the prostaglandin antagonist meclofenamate (14) does not necessarily imply that an increase in maternal arterial blood pressure after constriction of the distal aorta results from uterine release of prostaglandins if the increase in pressure was caused by discomfort.

It has been postulated that pregnancy-induced hypertension results from uterine ischemia. One study has shown that long-term constriction of the lower aorta of rabbits during pregnancy results in maternal hypertension (7), but this has not been a consistent finding (27). If maternal placental blood flow is strongly dependent on maternal arterial blood pressure, and if there is some mechanism for sensing inadequate placental flow, then a teleologically appropriate response to increase uteroplacental blood flow would be to increase maternal blood pressure. Because the placental vasculature is relatively resistant to the vasoconstrictive effects of substances such as angiotensin (28), it is conceivable that the uterus could release a vasoactive substance that raises maternal blood pressure and at the same time increases placental flow. It is tempting to speculate that the increase in upper-body blood pressure seen in this study resulted from the release of such a vasoconstrictor agent from the uteroplacental unit. However, there is no direct evidence that links the increase in upper-body arterial blood pressure after this procedure with the clinical syndrome of pregnancy-induced hypertension.

That the uterus releases "ordinary" angiotensin in response to hypotension is unlikely, in view of our findings that circulating concentrations of angiotensin I and aPRA were unchanged and that there was no net release of aPRA from the uterus. In addition, Woods and Brooks (13) showed no increase in circulating angiotensin II after reducing uterine driving pressure by a method similar to ours in pregnant dogs, and they could not block the increase in upper-body blood pressure with an angiotensin-converting enzyme inhibitor during a constant infusion of angiotensin II.

However, there was a release of trypsin-activated renin activity into the uterine vein after reduction of distal aortic pressure that may have accounted for the increase in circulating arterial tPRA. Although there was not a statistically significant net uterine release of tPRA during the control period in this study, we have found a net uterine release of tPRA during the control period of 84.91 $\pm 19.00\left(\mathrm{ng} \cdot \mathrm{mL}^{-1} \cdot \mathrm{h}^{-1}\right)\left(\mathrm{mL} \cdot \mathrm{min}^{-1}\right)(p<0.001)$ by combining data from this and our previous study (5). Combining data from both studies still did not demonstrate any net release of aPRA from the uterus under any conditions. It is known that the renin content in uterine tissues increases 40 -fold during pregnancy in the rabbit, whereas renal renin decreases slightly, and that the renin in the nongravid uterus is predominately in the inactive form (29). The form of renin predominately produced by cultured human decidual cells is also prorenin (30). The concentration of prorenin in the uterine veins of women is often higher than in their arteries when sampling is done at the time of cesarean section (31). The reason for the large increase in uterine renin during pregnancy is unknown, as is the reason for the uterine release of this large molecular weight form of renin. There is no known role for circulating prorenin, but elevations in circulating prorenin have been reported in association with various pathologic states $(32,33)$. It has also been speculated that an enzymatically active site on prorenin can be exposed during a conformational change resulting from binding of the peptide to a receptor.

In summary, this study demonstrates that there is no substantial autoregulation of maternal placental flow $1 \mathrm{~h}$ after reduction in uterine driving pressure in the unanesthetized rabbit. Also, there is no evidence for a specific local renin-angiotensin mechanism acting to support placental blood flow within this period of time. The effect of captopril on placental blood flow reported in our previous study can now be explained in its entirety by the associated reduction of maternal arterial blood pressure. There is no evidence for the net release of the active form of renin from the uteroplacental circulation in the basal state or after uterine perfusion pressure is decreased. A usually inactive form of renin is released by the uterus of the pregnant rabbit, and its release seems to be stimulated by uterine arterial hypotension or by reduced uteroplacental flow. Although arterial blood pressure increased above an inflated occluder placed around the aorta between the renal and ovarian arteries in pregnant does, a causal relationship between uterine arterial hypotension and the uterine release of a specific vasoactive substance has not yet been demonstrated.

Acknowledgments. The authors are indebted to Bob Weber and Pat Renwick for indispensible technical assistance as well as to Tom Green and Kim Saunders for conscientious help.

\section{REFERENCES}

1. Berman W, Goodlin RC, Heymann MA, Rudolph AM 1976 Relationships between pressure and flow in the umbilical and uterine circulations of the sheep. Circ Res 38:262-266

2. Greiss FC 1966 Pressure-flow relationship in the gravid uterine vascular bed. Am J Obstet Gynecol 96:41-47

3. Venuto RC, Cox JW, Stein JH, Ferris TF 1976 The effect of changes in perfusion pressure on uteroplacental blood flow in the pregnant rabbit. J Clin Invest 57:938-944 
4. Ferris TF, Weir EK 1983 Effect of captopril on uterine blood flow and prostaglandin E synthesis in the pregnant rabbit. J Clin Invest 71:809-815

5. Binder ND, Faber JJ 1992 Effects of captopril on blood pressure, placental blood flow and uterine oxygen consumption in pregnant rabbits. J Pharmacol Exp Ther 260:294-299

6. Abitbol MM, Pirani CL, Ober WB, Driscoll SG, Cohen MW 1976 Production of experimental toxemia in the pregnant dog. Obstet Gynecol 48:537-548

7. Abitbol MM, Gallo GR, Pirani CL, Ober WB 1976 Production of experimental toxemia in the pregnant rabbit. Am J Obstet Gynecol 124:460-470

8. Abitbol MM, Ober WB, Gallo GR, Driscoll SG, Pirani CL 1977 Experimental toxemia of pregnancy in the monkey, with a preliminary report on renin and aldosterone. Am J Pathol 86:573-590

9. Abitbol MM 1982 Simplified technique to produce toxemia in the rat: considerations on cause of toxemia. Clin Exp Hypertens [B] 1:93-103

10. Cavanaugh D, Rao PS, Knuppel RA, Desai U, Balis JU 1985 Pregnancyinduced hypertension: development of a model in the pregnant primate (Papio anubis). Am J Obstet Gynecol 151:987-999

11. Leffler CW, Hessler JR, Green RS, Fletcher AM 1986 Effects of sodium chloride on pregnant sheep with reduced uteroplacental perfusion pressure. Hypertension 8:62-65

12. Losonczy G, Todd H, Palmer DC, Hertelendy F 1986 Prostaglandins, norepinephrine, angiotensin II and blood pressure changes induced by uteroplacental ischemia in rabbits. Clin Exp Hypertens [B] 5:271-293

13. Woods LL, Brooks VL 1989 Role of the renin-angiotensin system in hypertension during reduced uteroplacental perfusion pressure. Am J Physiol 257:R204-R209

14. Woods LL 1989 Importance of prostaglandins in hypertension during reduced uteroplacental perfusion pressure. Am J Physiol 257:R1558-R1561

15. Anderson DF, Faber JJ 1984 Regulation of fetal placental blood flow in the lamb. Am J Physiol 247:R567-R574

16. Anderson DF, Parks CM, Faber JJ 1987 Arterial pressure after chronic reductions in suprarenal aortic flow in fetal lambs. Am J Physiol 253:H838H844

17. Binder ND, Anderson DF 1992 Plasma renin activity responses to graded decreases in renal perfusion pressure in fetal and newborn lambs. Am J Physiol 262:R524-R529

18. Hsueh WA, Luethscher JA, Carlson EJ, Grislis G, Fraze E, McHargue A 1982 Changes in active and inactive renin throughout pregnancy. J Clin Endocrinol Metab 54:1010-1016
19. Bhattacharya J, Beilin LJ 1980 Left ventricular cannulation for microsphere estimation of rabbit renal blood flow. Am J Physiol 238:H736-H739

20. Makowski EL, Meschia G, Droegemueller W, Battaglia FC 1968 Measure ment of umbilical arterial blood flow to the sheep and the placenta in utero. Distribution to cotyledons and the intercotyledonary chorion. Circ Res 23:623-631

21. Venuto RC 1980 The use of radiolabelled microspheres to measure uteroplacental blood flow. In: Moawad AH, Lindheimer MD (eds) Uterine and Placental Blood Flow. Masson, New York, pp 39-44

22. Rankin JHG, De Lone D, Phernetton TM 1988 Placental vascular response to prostaglandin $I_{2}$ in the rabbit. J Dev Physiol 10:541-546

23. Cho KW, Koh GY, Kim SH, Seul KH 1987 Unilateral renal arterial infusion and renal vein catheterization in rabbits. Renal Physiol 10:93-101

24. Winer BJ 1971 Statistical Principles in Experimental Design, 2nd Ed. Mc Graw-Hill, New York

25. Brown GP, Venuto RC 1991 Renal blood flow response to angiotensin II infusions in conscious pregnant rabbits. Am J Physiol 261:F51-F59

26. Pedron SL, Reid DL, Barnard JM, Henry JB, Phernetton TM, Rankin JHG 1992 Differential effects of intravenous hydralazine on myoendometrial and placental blood flow in hypertensive pregnant ewes. Am J Obstet Gynecol 167:1672-1678

27. Reddy GSR, Gallery EDM, Gyory AZ 1984 Experimental pregnancyassociated hypertension in the pregnant rabbit. Clin Exp Hypertens [B] 3:85-95

28. Rosenfeld CR, Naden RP 1989 Uterine and nonuterine vascular responses to angiotensin II in ovine pregnancy. Am J Physiol 257:H17-H24

29. Dzau VJ, Gonzalez D, Ellison K, Churchill S, Emmett N 1987 Characterization of purified rabbit uterine renin: influence of pregnancy on uterine inactive renin. Endocrinology 120:358-364

30. Shaw KJ, Do YS, Kjos S, Anderson PW, Shinagawa T, Dubeau L, Hsueh WA 1989 Human decidua is a major source of renin. J Clin Invest 83:2085-2092

31. Brar HS, Do Y-S, Tam HB, Valenzuela GJ, Murray RD, Longo LD, Yonekura ML, Hsueh WA 1986 Uteroplacental unit as a source of elevated circulating prorenin levels in normal pregnancy. Am J Obstet Gynecol 155:1223-1226

32. Derkx FHM, Schalekamp MADH 1988 Human prorenin: pathophysiology and clinical implications. Clin Exp Hypertens [A] 10:1213-1225

33. Osmond DH, Sealey JE, McKenzie JK 1991 Activation and function of prorenin: different viewpoints. Can J Physiol Pharmacol 69:1308-1314 